Crime, Histoire \& Sociétés / Crime, History \& Societies

Vol. 21, n² | 2017

L'histoire de la criminalité et de la justice pénale : propositions de recherche pour le $21^{\mathrm{e}}$ siècle

\title{
Religion and Penal Justice in the Roman-German Empire (from the Fourteenth to Seventeenth Centuries)
}

Peter Schuster

\section{Q OpenEdition}

\section{Journals}

Electronic version

URL: http://journals.openedition.org/chs/1930

DOI: $10.4000 /$ chs. 1930

ISSN: 1663-4837

Publisher

Librairie Droz

Printed version

Date of publication: 31 December 2017

Number of pages: 251-259

ISSN: $1422-0857$

\section{Electronic reference}

Peter Schuster, "Religion and Penal Justice in the Roman-German Empire (from the Fourteenth to Seventeenth Centuries)", Crime, Histoire \& Sociétés / Crime, History \& Societies [Online], Vol. 21, n² I 2017, Online since 19 July 2020, connection on 13 January 2021. URL: http:// journals.openedition.org/chs/1930 ; DOI: https://doi.org/10.4000/chs.1930 


\title{
Religion and Penal Justice in the Roman-German Empire
}

\author{
(from the Fourteenth to Seventeenth Centuries)
}

\author{
Peter Schuster
}

Uuntsville, Texas: "He entered the Death House at 12:02 a.m. He was carrying

- a white Bible. He asked for and was granted permission to kneel and pray. "Oh God, have mercy on these people" he intoned. "Have mercy on me, and bless these people". He died with the Bible in his lap. When the electricity shocked him, the Bible spun from his lap with such speed that it landed in the witness area. The doctor pronounced him dead at 12:08 a.m., July 30, 1964"'.

This macabre scene should come as no great surprise. Indeed, only a few years before, Albert Camus had emphasized that the death penalty has been a religious punishment for centuries ${ }^{2}$. However, this makes it all the more surprising that so little attention has been paid to the influence of religion on the history of the death penalty. This article specifically asks how executions in early modern Europe became religious stagings and what this meant for the history of the death penalty. It will start by examining how religious elements found their way into the execution ritual. The next step will show that both the increase in executions during the sixteenth century and the gradual emancipation during this period from the brutal forms of killing practiced in the Middle Ages were closely linked to the religious upheavals of the time.

\section{WHEN DID PRIESTS BECOME INVOLVED WITH THE SCAFFOLD?}

Courts in the Middle Ages did not automatically allow an offender who was sentenced to death to confess and receive the sacraments before being executed. In the thirteenth century, the Franciscan monk Salimbene of Parma reported how several supporters of the Pope were executed at the hands of the Imperial party's leader in Reggio. After receiving the death sentence, the offenders asked for permission to go to confession and receive the sacraments. Their request was heartlessly denied, and it was argued that it was not necessary for them to confess, because - as members of the church - they were already devout and would find their way to paradise without either confession or the Eucharist ${ }^{3}$.

Reid and Gurwell (2001, p.190).

2 "En fait, le châtiment suprême a toujours été, à travers les siècles, une peine religieuse", Camus (1957, p.161). An English translation of the text can be found in Camus (1960).

3 Schuster (2003, p.223).

Crime, Histoire \& Sociétés / Crime, History \& Societies 2017, vol. 21, n 2, pp. 251-259. 
The early medieval church had already spoken out against the practice of denying sacraments to offenders committing harshly punished sins. In 630, a synod in Reims decreed that even murderers should be allowed the Eucharist if they sincerely regretted their deeds. In 847, a synod in Mainz referred to the penitent thief on the cross, symbolizing that even criminals must be allowed to find their way to remorse and repentance right up to their last breath. All these synodal letters quote Ezekiel 33, 11: "Say to them, As I live, said the Lord GOD, I have no pleasure in the death of the wicked; but that the wicked turn from his way and live: turn you, turn you from your evil ways; for why will you die, O house of Israel"4?

Although these decrees and synods were only moderately successful, practices began to change at the end of the fourteenth century. However, it was not until 1500 that the right to confession prevailed. In 1397, Jean Gerson wrote a letter to the French king strongly demanding the abolition of the previous practice of denying confession. Nonetheless, this abolition was to be a long time coming. In the Empire, each court enjoyed independent jurisdiction, and there did not seem to be any great interest in the topic. The Imperial City of Constance was granted the Blutgerichtsbarkeit in 1416 and began to apply it immediately. However, it was almost twenty years before the religious needs of the condemned were taken into account. In 1434, two offenders sentenced to death asked to receive and were then given the sacraments. The next day, the city council discussed the issue. They decided not to promote it as a general practice, but to grant convicts their sacraments if requested. The Imperial city of Frankfurt came to a similar decision at roughly the same time: if a condemned person were to ask to receive the sacraments, they should receive them. There are no signs that the authorities took any particular interest in this. Indeed, it was the mendicant orders and the more committed members of the clergy who were particularly concerned with the salvation of the condemned. At times, their activities even triggered some rather strange discussions among the authorities. For example, in Strasbourg in 1461, some councilmen became concerned about the practice of confession in their city. They considered the activities of the clergy to be suspicious. Apparently, a number of convicts who had talked to a clergyman went on to withdraw their confessions in public just before the execution. This was said to have encouraged rumours among the people suggesting that the city council was using torture to elicit false confessions. To oppose this development, it was decided that confessions should be heard in the chapel near the gallows immediately before the execution instead of in the prison cell. However, this raised dissent: were confessions to take place at the site of execution, and how long might it take for convicts to unburden themselves? The fear was that if this led to a longer waiting period, especially in winter, horses might die of exposure or be otherwise harmed. But the considerate animal lover making this argument did not win. Starting in 1461, confession took place at the execution site ${ }^{5}$.

On the eve of the Reformation, every execution was a religious spectacle. Clerics accompanied the doomed criminals. Crosses were carried in front of them, hymns were sung, and prayers were said. One chronicler gave the following report: Around 1500, a young woman was supposed to be burned to death in Frankish Swabia. Before the fire was lit, one of the three clerics accompanying her said: "Liebe Frau, seid fest im christlichen Glauben und sterbt als ein Christenmensch" [Good woman,

Prosperi (2008, p.109-110).

Schuster (2016, p.76-79). 
be firm in your Christian belief and die a Christian]. She responded: "Ich will als Christenmensch sterben" [I want to die a Christian]. Hereupon the clerics spoke: "Wenn das Feuer entzündet wird, so schreit mit uns in Andacht und mit lauter Stimme 'Jesus Nazarenus, rex Judeorum, Herr, erbarme dich über mich'" [When the fire is ignited, cry with us devoutly and loudly "Jesus Nazarenus, rex Judeorum, Lord, have mercy upon me"]. And this she did as long as she could, until her voice was silenced by smoke and heat. Thus, she strongly indicated that she was a good Christian and died in a state of Christian devotion 6 .

By the late Middle Ages, execution sites had been transformed into holy settings. They were bordered by crosses and small chapels. The gallows and the wheel had become the epicentre of genuine Christian repentance and humility. Going to one's death could be understood as an "imitatio Christi". The doomed men and women radiated a certain holiness and sanctity.

\section{CHANGES INSPIRED BY THE REFORMATION}

It should not be forgotten that judges in the Middle Ages were laypersons. Late medieval courts and judges always has to be aware of how limited they were in determining the truth. The Sachsenspiegel reminded judges that they had been assigned to the court by God Himself. Therefore, they should be careful when handing down their sentences and always remember that they will face God's wrath and justice if they punish the innocent ${ }^{7}$. Reminding the judges of the Last Judgement was common practice in late medieval society. In an early edition of the so-called Bambergensis of 1507, the precursor of the famous Constitutio Criminalis of Charles V's reign in 1532, the Table of Contents is immediately followed by a woodcut depicting Christ as the judge in the Last Judgement.

The captions were directed towards the judges working with that law, and they delivered a firm warning: "Gedenck allezeit der leczten ding. So wird dir recht $(\mathrm{t})$ un gar gering"[Always remember the last day, so it will be easy for you to find a just sentence]. A quotation from the bible below confirms the message: "With what judgment ye judge, ye shall be judged" (Matthew 7:2) ${ }^{8}$. Pictures of the Last Judgement admonished the judges to exercise humility and restraint. They were a reminder that there was a higher court above them; a court that knew the truth, for it was God's court. The judges knew that the supreme judge in heaven could hold them accountable for their rulings. Nonetheless, God or a saint could already intervene to prevent the greatest injustices in this world by arranging a hanging miracle. If the rope broke during an execution and the condemned person survived, this was conceived as divine intervention, and the poor sinner would go free.

There is no doubt that attitudes towards law and criminal justice changed in the sixteenth century. Traditionally, German historians have tended to argue that this change was brought about by the Imperial penal law, the Constitutio Criminalis of 1532. However, they have tended to overlook the fact that the Constitutio Criminalis

Heinrich Deichsler's Chronik (1874, p.694).

Repgow, see Eckhardt Ed. (1933, p.51-52).

8 http://www.uni-mannheim.de/mateo/desbillons/bambi/seite15.html (January 2, 2017). 
retained a traditional approach. It proposed nothing new concerning the ways of punishment except to set standards for torture. I therefore argue that the promoter of change in criminal justice was the religious change brought about by the Reformation.

The judges in Reformation cities no longer had to fear God's punishment. The Reformation raised their status by liberating them from their limited view of the truth (veritas). This transformed them into infallible servants of God. For Luther and his supporters, all punishment and executions of penal sentences were the fulfilment of God's will. They believed that secular punishment was an expression of divine justice. When addressing the use of the death sentence, the famous reformer stated: "die hand, die solch schwerd fueret und wuerget, ist auch als denn nicht mehr menschen hand sondern Gottes hand, und nicht der mensch sondern Gott henget, redert, entheubt, würget und krieget" [the hand taking the sword to execute is also not just a man's hand, it is God's hand. And it is not man but God who hangs, breaks on the wheel, beheads, strangles, and catches the criminal] ${ }^{9}$. In the second half of the sixteenth century, Caspar Huberinus wrote a so-called "Trostbüchlein" aiming to give trainee clergy guidance on how to treat the dying. They were to instruct the condemned that they should willingly accept their fate because "solche züchtigung von GOTT selbst kombt" [such punishment comes from God Himself] ${ }^{10}$. Around 1600, the bailiff of the town of St. Gallen in Switzerland was convinced that "ain christenlich Oberkeit aus Gottes Befelch zu strafen schuldig seie" [Christian authorities are obliged to punish by divine order] ${ }^{11}$. Secular punishment could be understood as an expression of God's wrath over the offender's sins, as a "väterliche Züchtigung Gottes" [fatherly punishment by God] $]^{12}$.

During the sixteenth century, the established right to punish evolved into a duty in order to avoid God's wrath. If the authorities failed to punish an offence, God would become enraged and send disease, catastrophes, and war, argued the famous jurist, witch-hunter, and Protestant Benedikt Carpzow in the first half of the seventeenth century ${ }^{13}$. This argument was not really new, but in the late Middle Ages - to the best of my knowledge - only a few offences such as adultery, blasphemy, and gambling were thought to trigger God's wrath. Since the Reformation, every offence seems to have been regarded as an attack on the divine order. After the Reformation, there was no room for doubt about the courts' judgements. As Luther argued, false judgements were still possible, but that was never the fault of the judges, but rather that of the suspects; for instance if they gave a false confession when tortured, which was a grave $\sin ^{14}$.

Luther's thoughts on the relationship between the secular and the divine court of justice had a considerable impact on the practice of criminal justice. The number of death penalties rose during the sixteenth century. Doubt began to be cast on hanging miracles, because if every execution was a fulfilment of God's will, there was no more reason to expect God to intervene in a public execution. It was no accident that the first negation of a hanging miracle in Nuremberg happened in the very same

\footnotetext{
9 Cited in Martschukat (2000, p.13).

10 Huberinus (1567).

11 Cited in Moser-Nef (1951, p.39).

12 Cited in Brandt (1985, p.60).

13 Cited in Martschukat (2000, p.13).

14 Luther (Ed. 1919, p.39); Luther (Ed. 1912, p.81); Schmoeckel (2000, p.110).
} 
year as the city's conversion to Protestantism. In 1525, three men were hanged. In one case, the rope broke and the convicted thief fell to the ground. According to the tradition of the hanging miracle, he would then have to be set free. But in this case, he was led back to the gallows and hanged again. This practice was in accordance with the reformers' thinking. Johannes Bugenhagen, a close friend of Luther, argued, it would be contrary to all divine and human law if the culprit whose neck had been saved were to be freed ${ }^{15}$. Catholic territories followed this trend. In 1584, a thief was hanged in Bonn. The rope broke, he fell down, and broke his leg. His claim that this accident was grounds for mercy was rejected. He was led to the gallows again and put to death. We witness the same approach in the practice of drowning. In 1549, a woman survived drowning in Nuremberg, probably because the river Pegnitz by the Hallerwiesen, where the drowning was to take place, was silted and therefore not deep enough. One day prior to the failed execution, the executioner had been ordered to examine the depth of the water by the Hallerwiesen. Obviously he had made a mistake. But this did not save the poor sinner. In a second attempt, the executioner succeeded in ending the life of Margaret Wagnerin ${ }^{16}$.

We also observe a tendency for more executions to be carried out by sword. Breaking on the wheel and hanging became less frequent punishments to be administered only in severe cases. Instead, it became common practice to grant mercy to criminals sentenced to death by executing them with a sword. Execution by sword was regarded as less cruel and less defamatory. Many offenders were grateful for this act of mercy. It is generally argued that this trend towards execution by the sword represents a shift towards a more humane society. But what triggered this? In my opinion, this is, once again, a consequence of the Reformation. In a Catholic understanding, the wide variety of lethal punishments found in the late Middle Ages made sense: the cruelty of the execution reflected the cruelty of the deed. For a murderer, suffering a slow death on the wheel could be seen as an act of penance. A legal text from 1507 displays this. It contains a woodcut with the message: "Wenn du Geduld hast in der Pein, wird sie dir gar nützlich sein" [If you show patience in agony, it may be to your benefit] ${ }^{17}$. Suffering purified the soul.

In a Protestant understanding, this was an error. "In Protestant thinking physical suffering no longer had spiritual power"18. The 1569 church constitution of Wolfenbüttel stated that one should not follow the papacy and interpret execution as atonement for the sin, because forgiveness of sins comes only from Christ's death on the cross ${ }^{19}$. Hence, the need for a complex system of lethal punishments had disappeared. People sentenced to death were supposed to die, not to suffer. That is the reason why many convicts were granted mercy by putting them to death with the sword. In the second half of the sixteenth century, carrying out the penalty of breaking on the wheel or burning at the stake was frequently just a show for the spectators. Increasingly, executioners were being instructed to secretly kill the convict before

15 "Dat is wedder alle Gotlike unde mynschlike recht/ dat de misdeder los werde de den hals vorbraken hefft". Bugenhagen (ed. 1912), p.68. See also Lorentzen (2008, p.364-365).

16 Schuster (2016, p.244-245).

17 https://www.uni-mannheim.de/mateo/desbillons/bambi/seite77.html (January 2, 2017).

18 Wiltenburg (2012, p.152).

19 Brandt (1985, p.64-65). 
performing the announced punishment in order to prevent the tortures of a slow death ${ }^{20}$.

Hence, there are two trends: Firstly, an unconditional justification of the death penalty by Protestant reformers, which can be considered as the first theology of the death penalty; and secondly, a process towards more humaneness in the penal system through the growing dominance of executions by sword. Both of these developments were adopted by the Catholic Church over the course of the Counter-Reformation.

\section{PASTORAL CARE AND TERROR}

Those clerics who approached the condemned as comforters were solely concerned with the poor sinners' salvation. In both a Protestant and a Catholic understanding, repentance was necessary to save an offender's soul. The prerequisite for repentance was admission of one's crime and acceptance of one's sentence. The comforters' task was to attain this goal. Normally, they visited the convicts in prison and badgered them over a period of several days.

In Wittenberg in 1530, the Wroclow-born reformer Ambrosius Moibanus published a short essay entitled "Unterrichtung der Übeltäter, die man töten soll" [Instruction of offenders who are to be put death]. The text makes depressing reading, because it does not focus on giving convicts pastoral care and comfort. Instead, it delivers a theological justification for the death penalty and a macabre as well as notorious indoctrination for those awaiting their execution. It states that every crime is a crime before God and a great sin. This makes a convict's imminent execution an inevitable act and therefore nothing to be sorrowful about. One had to acknowledge one's sins: indeed, many saints were said to have asked God to let them die because of smaller sins simply to free them from this earthly vale of tears. Every criminal should therefore plead and seek (bidden und begeren) all the more to fight their wicked and evil flesh and blood with iron, steel, water, and fire and overcome their disposition to commit dreadful sins. Then God will no longer be wrathful but will show mercy and let the convict enter the Kingdom of God. Furthermore, convicts were to be instructed that being put to death by the will of God is for their best, so that they may sin no more. The reformer once more refers to the commendable way of life of the saints. Many were said to have found death by the hand of an executioner and taken their fate with joy. Quite a few supposedly approached their execution in an equitable frame of mind and with rejoicing hearts, warmly welcoming the "mordtlike gerust" [lethal scaffold] and even kissing it. They were consumed with joy because finally, there would be an end to their guilt. In accordance with such role models, convicts should pray to God that He grant them mercy, patience, and a heart willing to die. They should praise God and thank him for the impending end since it would offer them a chance to cease sinning ${ }^{21}$.

Naturally, this form of pastoral care turned into psychological terror for convicts claiming to be innocent. The clerics insinuated that the offenders were undiscerning and were risking their salvation. A Lutheran priest from Nuremburg, Johannes Hagendorn, kept a journal of his visits to the doomed. It is a document of horror. When he was successful and the offenders accepted their fate with repentance, he

20 Schuster (2016, p.242-243).

21 Moibanus (1530). 
speaks in highly approbatory terms of the executed and wished them eternal life. However, he gets cynical at times. Hagendorn writes about a murderer who was broken on the wheel: "Hat 21 Stöße mit dem Rad bekommen. Die ersten zwei auf den Hals, danach 6 oder 8 auf das Herz, endlich sind ihm Arme und Beine zerstoßen worden. Gott möge ihm eine fröhliche Auferstehung verleihen" [Received 21 blows with the wheel. The first two to the throat, then 6 or 8 to the heart; finally his arms and legs were crushed. May God grant him a joyful resurrection]. He wrote of one thief in 1610: "Sie hielt dem Nachrichter den Nacken redlich hin und entschlief also in Christo" [She righteously turned her neck to the executioner and passed away peacefully in Christ]. Can one really think about resurrection while being broken on the wheel? Can one "pass away peacefully" on the scaffold? It all seems rather unlikely ${ }^{22}$.

If convicts struggled and refused to repent of their foul deeds, Hagendorn let them feel his entire contempt. One convict, who complained about having been hit on his way to the execution site, was chided with Hagendorn's anger: "What do you care about your body, you had better care for your soul" ${ }^{23}$. Convicts who maintained their innocence and did not show repentance were threatened, shouted at, and put under immense pressure. Such practices did not remain unobserved by contemporaries. In 1635, the Lutheran pastor Johannes Matthäus Meyfart gave the following appraisal of his fellow brethren's endeavours: "diese Tortur der Geistlichen sey weit schärffer als der Hencker: Denn die Hencker quelen nur den Leib/ solche Geistlichen quelen die Seele" [The clergy's torture weighs a lot heavier than that of the executioners: for executioners torture only the body, whereas the clergy torture the soul $]^{24}$.

\section{RELIGIOUS CRITICISM OF THE DEATH PENALTY}

One principle of the Reformation was the "sola scriptura". Jurisdiction was constrained to align itself with Holy Scripture. It was particularly sex offences such as incest, adultery, and homosexuality that should be punished more harshly, that is, with death. And that is exactly what happened. Sixteen-year-old girls who had had intercourse with their fathers and brothers over several years were executed relentlessly ${ }^{25}$. Today, we would call this sexual abuse and protect the girl.

But the majority of executions were for theft. Over time, a consistent proportion of about 75 per cent of offenders were sentenced to death for crimes against property. This finding receives far too little attention from historians: the death penalty was never used as a state-operated weapon to keep violence at bay. It was far more a means to protect property, and this is the point addressed by contemporary critics. It was mainly Calvinists who pointed out that, according to the sola scriptura in the Holy Scripture, the death penalty was not intended for thieves. This led straight to the opening of the first tuchthuis [penitentiary] in Amsterdam. The decision to open a penitentiary in Amsterdam immediately followed the execution of a sixteen-year-

22 Schuster (2016, p.265-266).

23 Germanisches Nationalmuseum Nürnberg, Hs.3857, fol.84vf.

24 Meyfart (1635, p.198); http://diglib.hab.de/drucke/323-5-theol-2/start.htm (January 2, 2017).

25 Keller (1979, p.21); Grieb (2010, p.371). 
old thief in 1589. It took several years to develop and discuss different concepts, and the penitentiary known as the Rasphuis finally opened its doors in 1596. Two years after it was founded, one of the city's leading politicians, Cornelis Pietersz Hooft, reminisced about the motives. He told how the members of the district court had been extremely reluctant to sentence thieves to death, even though this was the law of the state. He noted: "The reluctance of the gentlemen who objected to such penalties was based, I believe, upon the following: the Old Testament does not prescribe the death penalty for theft, an argument which I do not want to belittle. I know very well that the deliberations made on such matters for many years and several times are the principal cause for the foundation of the tuchthuis within this city"26.

In summary, to gain an understanding of the use of the death penalty at the beginning of modern times, it is necessary to look back at the Middle Ages. Hence, this topic cannot be handled within the traditional periodization. And the changes over the course of the sixteenth century - that is, the progress towards executions by the sword and the adoption of new capital offenses such as incest or infanticide - can be explained only by the religious controversies of the times. It was not jurists who changed the death penalty, it was above all theologians. For them, executions were one-of-a-kind services. It was also religious considerations that led to the development of alternatives to the death penalty. Without the Reformation, penitentiaries would never have been founded. Although they were certainly not an immediate success, they did become established and went on to make a decisive contribution to what has been a gradual decline in death sentences since the early seventeenth century.

Prof. Dr. Peter Schuster Faculty of History, Philosophy and Theology

University of Bielefeld peter.schuster@uni-bielefeld.de

\section{BIBLIOGRAPHY}

Brandt, P. (1985) Die evangelische Strafgefangenenseelsorge. Geschichte, Theorie, Praxis, Göttingen: Vandenhoeck \& Ruprecht.

Bugenhagen, J. (1912) Johannes Bugenhagens Braunschweiger Kirchenordnung 1528, Bonn: Hans Lietzmann ed.

Camus, A. (1957) Réflexions sur la Guillotine, in Camus, A. and Koestler, A. (Eds.), Réflexions sur la Peine, Paris: Calmann-Lévy.

Camus, A. (1960) Resistance, Rebellion and Death, New York: Knopf.

Grieb, M. (Ed.) (2010), Die Henker von Nürnberg und ihre Opfer. Folter und Hinrichtungen in den Nürnberger Ratsverlässen 1501 bis 1806, Nürnberg: Stadtarchiv.

Heinrich Deichsler's Chronik 1488-1506 (1874), in Die Chroniken der fränkischen Städte. Nürnberg V (Die Chroniken der deutschen Städte vom 14. bis ins 16. Jahrhundert, Bd. XI), Leipzig: Hirze.

26 Cited in Spierenburg (1991, p.44). 
Keller, A. (Ed.) (1979), Maister Franntzn Schmidts Nachrichters inn Nürnberg all sein Richten, 2nd ed., Neustadt an der Aisch: Ph. C.W. Schmidt.

Lorentzen, T. (2008) Johannes Bugenhagen als Reformator der öffentlichen Fürsorge, Tübingen: Mohr Siebeck.

Luther, M. (1912) Martin Luthers Werke, Kritische Gesamtausgabe, Tischreden I, Weimar: Böhlau.

Luther, M. (1919) Martin Luthers Werke, Kritische Gesamtausgabe, Tischreden V, Weimar: Böhlau.

Martschukat, J.A. (2000) Inszeniertes Töten. Eine Geschichte der Todesstrafe vom 17. bis zum 19. Jahrhundert, Köln: Böhlau.

Moser-Nef, C. (1951) Die freie Reichsstadt und Republik Sankt Gallen, Bd. 5: Geschichte ihres Strafrechts 1, Zürich: Orell Fuessli.

Prosperi, A. (2008) Consolation or Condemnation. The Debates on Withholding Sacraments from Prisoners, in Terpstra, N. (Ed.), The Art of Executing Well. Rituals of Execution in Renaissance Italy, Kirksville: Turman State University Press.

Reid, D. and Gurwell, J. (Eds.) (2001) Have a Seat, Please, Huntsville: Texas Review Press.

Repgow, E. (1933) (ed. Eckhardt, K.A.) Sachsenspiegel. Landrecht, Hannover.

Schmoeckel, M. (2000) Humanität und Staatsraison. Die Abschaffung der Folter in Europa und die Entwicklung des gemeinen Strafprozeß- und Beweisrechts seit dem hohen Mittelalter, Köln: Böhlau.

Schuster, P. (2003) Hinrichtungsrituale in der beginnenden Neuzeit. Anfragen aus dem Mittelalter, in Schnabel-Schüle, H., and Rudolph, H. (Eds.), Justiz=Justice=Justicia . Rahmenbedingungen des Strafrechts in der Frühen Neuzeit, Trier: Kliomedia.

Schuster, P. (2016) Verbrecher, Opfer, Heilige. Eine Geschichte des Tötens, Stuttgart: KlettCotta, 2nd. ed.

Spierenburg, P. (1991) The Prison Experience. Disciplinary Institutions and Their Inmates in Early Modern Europe, New Brunswick and London: Amsterdam University Press.

Wiltenburg, J. (2012) Crime and Culture in Early Modern Germany, Charlottesville: University of Virginia Press.

\section{Primary Sources}

Bambergische Halßgerichtsordnung (Bambergensis), Bamberg, 1507 [On line] http://www. uni-mannheim.de/mateo/desbillons/bambi.html.

Huberinus, Caspar, Trostbüchlein aus h. göttlicher Schrift, Nürnberg 1567 [On line] http:// www.mdz-nbn-resolving.de/urn/resolver.pl?urn=urn:nbn:de:bvb:12-bsb10193942-6.

Meyfart, J.M., Christliche Erinnerung an Gewaltige Regenten vnd Gewissenhaffte Praedicanten wie das abschewliche Laster der Hexerey mit Ernst außzurotten aber in Verfolgung desselbigen auff Cantzeln vnd in Gerichtsheusern sehr bescheidentlich zu handeln sey, Schleusingen, 1635 [On line] diglib.hab.de/drucke/323-5-theol-2/start.htm

Moibanus, A. (1530) Underrichtynge der Öveldeder, de me döden schal, Wittenberg, HerzogAugust-Bibliothek Wolfenbüttel, Signature: A: 1118.4 Theol. 4. 